\title{
Choroba kociego pazura - lekceważone schorzenie
}

\author{
Cat scratch disease - an underestimated diagnosis \\ Joanna Szaleniec, Krzysztof Oleś, Jacek Składzień, Paweł Stręk
}

\begin{abstract}
SUMMARY
Introduction: Cat scratch disease is a rare and frequently underestimated cause of lymphadenopathy, which may occur also in the head and neck. The infection is most commonly caused by intracellular bacilli Bartonella, transmitted by domestic animals.

Aim: We present a case report of a patient treated in the Department of Otolaryngology UJ CM in Krakow. The patient presented with a neck tumor. Due to unclear clinical manifestation he underwent surgical treatment. The postoperative histopathological examination suggested cat scratch disease. In detailed anamnesis the patient admitted contact with cats and dogs in his household. No posoperative complications were observed.

Conclusions: In every case of neck tumor it is advisable to consider cat scratch disease, remembering that exclusion of a neoplastic process remains a priority.

Hasła indeksowe: choroba kociego pazura, łagodna limforetikuloza, szyja, węzły chłonne

Key words: cat-scratch disease, inoculative lymphoreticulosis, neck, lymph nodes
\end{abstract}

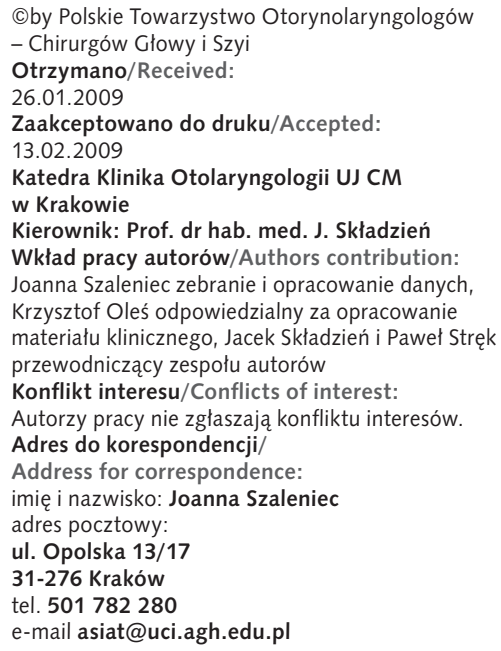

Cby Polskie Towarzystwo Otorynolaryngologów - Chirurgów Głowy i Szyi Otrzymano/Received:

26.01.2009

Zaakceptowano do druku/Accepted:

13.02.2009

Katedra Klinika Otolaryngologii UJ CM

w Krakowie

Kierownik: Prof. dr hab. med. J. Składzień

Wkład pracy autorów/Authors contribution: Joanna Szaleniec zebranie i opracowanie danych, Krzysztof Oleś odpowiedzialny za opracowanie materiału klinicznego, Jacek Składzień i Paweł Stręk przewodniczący zespołu autorów Konflikt interesu/Conflicts of interest:

Autorzy pracy nie zgłaszają konfliktu interesów.

Adres do korespondencji/

Address for correspondence:

imię i nazwisko: Joanna Szaleniec

adres pocztowy:

ul. Opolska 13/17

31-276 Kraków

tel. 501782280

e-mail asiat@uci.agh.edu.pl

Otolaryngol Pol 2009; 63 (3): $271-273$

\section{Wstęp}

Choroba kociego pazura (łagodna limforetikuloza, cat scratch disease) jest jedną z przyczyn miejscowego powiększenia węzłów chłonnych, zwłaszcza u dzieci i młodzieży. Może mieć nietypowy obraz kliniczny i manifestować się różnorodnymi, niekiedy zaskakującymi objawami, również w obrębie głowy i szyi [1]. Schorzenie to często bywa jednak pomijane w diagnostyce różnicowej, a wiedza dotycząca jego rozpoznawania i leczenia wydaje się być niedostatecznie rozpowszechniona i bagatelizowana. Zachorowalność w Polsce szacuje się zaledwie na 0,15 na 100 tysięcy mieszkańców [2], jednak najprawdopodobniej liczba ta jest znacznie zaniżona ze względu na rzadkie uwzględnianie tego schorzenia w rutynowej diagnostyce.

Choroba powodowana jest prawdopodobnie przez bakterie - laseczki wewnątrzkomórkowe $z$ rodzaju Bartonella (gł. B. hanselae). Do zakażenia dochodzi najczęściej wskutek podrapania lub ugryzienia przez kota, jednak opisywano również zachorowania po polizaniu przez kota uszkodzonej skóry. Choroba manifestuje się powiększeniem węzłów chłonnych i stanem podgorączkowym. U dzieci może dochodzić do zakażenia spojówki (przy lizaniu oczodołu przez kota) i wówczas może wystąpić syndroma oculoglandularis, objawiający się obrzękiem tkanek oczodołowych, w tym zagałkowych i powiększeniem węzłów chłonnych szyjnych II przestrzeni w obrębie zlewiska oczodołu. Źródłem infekcji mogą być również psy, króliki, gryzonie, wiewiórki czy małpy. Nie zanotowano natomiast transmisji patogenu z człowieka na człowieka. Pomiędzy zwierzętami zakażenie przenoszone jest przez pchły, jednak nie ma dowodów na możliwość przeniesienia infekcji przez pchłę ze zwierzęcia na człowieka [3]. U zwierząt zakażenie zwykle przebiega bezobjawowo, w związku z czym potwierdzenie lub wykluczenie nosicielstwa u konkretnego zwierzęcia jest trudne i kosztowne, a próby eradykacji nosicielstwa bywają nieskuteczne. Niemniej jednak wydaje się, że zakażony kot może być źródłem infekcji dla człowieka jedynie przez ograniczony czas (około 3 tygodni), więc zazwyczaj w momencie rozpoznania choroby u człowieka, kot nie stanowi już zagrożenia dla kolejnych osób. W związku z tym, nie istnieją racjonalne przesłanki przemawiające za uśmiercaniem lub pozbywaniem się z domu zwierzęcia, które stało się źródłem infekcji. Co więcej szacuje się, że w Polsce około 85\% kotów może być nosicielami laseczek z rodzaju Bartonella [4], co oznacza, że narażenie na tę infekcję jest powszechne.

Po kilku dniach od zakażenia u człowieka w miejscu wniknięcia drobnoustroju tworzy się zmiana pierwotna, mająca postać grudki, pęcherzyka lub krosty. Zmiana ta goi się po 1-4 tygodniach nie pozostawiając blizny i na ogół nie zostaje zauważona przez pacjenta [5]. W następnym etapie dochodzi do powiększenia jednego lub kilku węzłów chłonnych drenujących sąsiedztwo urazu. Zazwyczaj są to węzły pachowe (45\%) lub szyjne bądź podżuchwowe (25\%), ale dla narządów laryngologicznych reakcja jest zawsze $z$ węzłów typowego zlewiska 
dla danego narządu, a więc nie $z$ węzłów pachowych. Ich rozmiary najczęściej wahają się w granicach 1-5 $\mathrm{cm}$, chociaż obserwowano nawet guzy wielkości ponad $10 \mathrm{~cm}$. Węzły chłonne są przesuwalne względem otaczających tkanek, często bolesne. W około 20-30\% przypadków może dochodzić do zropienia zajętego węzła, a nawet do wytworzenia przetoki [2]. Autorzy nigdy nie obserwowali przetok, a skóra nad zajętymi węzłami nie była zmieniona zapalnie. Przebieg choroby jest zazwyczaj łagodny i ma charakter samoograniczajcy się. Limfadenopatii może towarzyszyć podwyższona liczba neutrofili i miernie zwiększona leukocytoza. Powiększone węzły chłonne na ogół ulegają samoistnemu zmniejszeniu po upływie 4-6 tygodni, jedynie w nielicznych przypadkach limfadenopatia utrzymuje się przez dłuższy okres (nawet ponad 12 miesięcy).

U nielicznych pacjentów dochodzi do wystapienia powikłań choroby kociego pazura. U 2-3\% rozwija się encefalopatia, manifestująca się zaburzeniami świadomości, drgawkami lub objawami ogniskowego uszkodzenia ośrodkowego układu nerwowego, występującymi w okresie 1 do 6 tygodni od powiększenia węzłów chłonnych. Chorobie może towarzyszyć jednostronne upośledzenie widzenia spowodowane zapaleniem siatkówki i nerwu wzrokowego, rumień guzowaty, zapalenie wsierdzia, niedokrwistość, powiększenie wątroby, zapalenie płuc, zapalenie stawów, zapalenie szpiku i kości [5], aczkolwiek w materiale Kliniki Otolaryngologii UJ takich powikłań nie obserwowano. U chorych immunokompetentnych nie zarejestrowano żadnego przypadku zgonu $\mathrm{z}$ powodu choroby kociego pazura, jednak u osób z upośledzoną odpornością ma ona niekiedy ciężki przebieg [5]. Uważa się, że przebycie choroby kociego pazura daje długotrwałą odporność [3].

Hodowla laseczek $\mathrm{z}$ rodzaju Bartonella jest trudna, więc klasyczne posiewy zazwyczaj nie zapewniają rozstrzygającego wyniku. W celu potwierdzenia choroby kociego pazura konieczne jest badanie serologiczne (metodą ELISA lub IFA) celem oznaczenia poziomu swoistych IgM i IgG (w Polsce badanie to można przeprowadzić w Pracowni Chlamydii, Riketsji i Krętków Odzwierzęcych Państwowego Zakładu Higieny) [2]. Metoda PCR, stosowana do wykrywania materiału genetycznego Bartonella np. w bioptacie $\mathrm{z}$ węzła chłonnego, nie jest szeroko dostępna. Chorobę kociego pazura można rozpoznać również na podstawie badania histopatologicznego (początkowo obserwuje się tworzenie ziarniniaków z komórek nabłonkowatych, które otaczają ogniska granulocytów obojętnochłonnych wymieszanych $\mathrm{z}$ fragmentami rozpadłych komórek) [6].

Choroba kociego pazura wymaga różnicowania z innymi schorzeniami powodującymi powiększenie węzłów chłonnych: toksoplazmozą, mononukleozą, tularemią, gruźlicą lub zakażeniem prątkami atypowymi, a także chorobami nowotworowymi (zwłaszcza chorobami rozrostowymi układu krwiotwórczego).
Łagodna limforetikuloza, jako schorzenie samoograniczające się, zazwyczaj wymaga jedynie leczenia objawowego - przeciwbólowego i przeciwgorączkowego. Konieczność stosowania antybiotyków jest sprawą otwartą, jakkolwiek notowano poprawę po zastosowaniu wielu grup antybiotyków (azytromycyna, rifampicyna, trimetoprim/sulfmetoxazol, ciprofloksacyna, antybiotyki B-laktamowe, doksycyklina, klarytromycyna) [5], zwłaszcza przy podwyższonej temperaturze i leukocytozie oraz tendencji do tworzenia ropni.

W przypadku zropienia węzła konieczne jest typowe postępowanie, zaś przy dłużej utrzymującym się powiększonym węźle chłonnym wskazane jest jego usunięcie w całości i potraktowanie jako poszerzony materiał do badania histopatologicznego dla wykluczenia procesu rozrostowego [7].

\section{Cel pracy}

Przedstawiamy opis przypadku u pacjenta leczonego w Klinice Otolaryngologii UJ CM w Krakowie.

\section{Opis przypadku}

Pacjent J.K., lat 58, nr historii choroby 1146/08, zgłosił się do Kliniki Otolaryngologii UJ CM w Krakowie z powodu guza szyi, który pojawił się około 2 miesiące wcześniej kojarzył go z przebytą wcześniej infekcją górnych dróg oddechowych. Przyjmował wówczas antybiotyk doustnie, który spowodował subiektywną poprawę.

$\mathrm{W}$ badaniu fizykalnym przy przyjęciu stwierdzono na szyi po stronie prawej guz w II przedziale węzłowym o średnicy około $3 \mathrm{~cm}$, miękki, niebolesny, ruchomy względem otaczających tkanek. Skóra nad guzem była zaczerwieniona. Pacjent poinformował o okresowych stanach podgorączkowych. Nie skarżył się na żadne inne dolegliwości. W badaniach laboratoryjnych nie stwierdzono istotnych odchyleń od stanu prawidłowego poza leukocytozą 12100/ul. W USG szyi opisano guz jako strukturę hypoechogeniczną o wymiarach 31x10 $\mathrm{mm}$. Ze względu na niejednoznaczny obraz kliniczny chory został zakwalifikowany do leczenia operacyjnego. W trakcie zabiegu operacyjnego po odsłonięciu przedniego brzegu mięśnia mostkowo-obojczykowo-sutkowego i żyły szyjnej wewnętrznej stwierdzono naciek zapalny oraz owrzodzenie kraterowate o średnicy około $3 \mathrm{~cm}$, które propagowało aż do dna jamy ustnej. Guz usunięto w całości. W badaniu śródoperacyjnym nie stwierdzono nowotworu.

W okresie pooperacyjnym u chorego stosowano ceftriakson, metronidazol a po 5 dniach pefloksacynę.

$\mathrm{W}$ badaniu histopatologicznym materiału operacyjnego stwierdzono obecność węzłów chłonnych $\mathrm{z}$ obrazem zmian ziarniniakowych ropiejących (suppurative granulomatous lymphadenopathy). W badanym materiale występowały liczne zlewające się ziarniniaki 
z komórek nabłonkowatych i nielicznych olbrzymich wielojądrzastych, w części centralnej z nieregularnymi obszarami martwicy, w obrębie której widoczne były nieliczne granulocyty, a wokół obszarów martwicy palisadowato układające się histiocyty. Barwieniem Ziehla-Nielsena nie uwidoczniono prątków kwasoopornych. Obserwowane zmiany sugerowały konieczność uwzględnienia w diagnostyce różnicowej przede wszystkim choroby kociego pazura.

W szczegółowym wywiadzie, poszerzonym po uzyskaniu wyniku badania histopatologicznego, chory potwierdził liczne kontakty z kotem i psem, jednak nie przypominał sobie epizodu zadrapania przez którekolwiek ze zwierząt ani kontaktu śliny zwierząt $z$ uszkodzoną skórą, nie zaobserwował również wystąpienia zmiany pierwotnej.

Chory wygoił się per primam. Przebieg po zabiegu był bez temperatury. Pacjent pozostaje na obserwacji od 4 miesięcy. Nie stwierdzono u niego niepokojących objawów, mogących sugerować rozwój powikłań. U żadnej z osób z otoczenia chorego, mających kontakt z tymi samymi co on zwierzętami, nie zaobserwowano objawów choroby.

\section{Omówienie}

Różnorodność objawów klinicznych, jakimi może manifestować się choroba kociego pazura, a także brak charakterystycznych cech pozwalających odróżnić ją od innych schorzeń, czyni tę chorobę niezwykle trudnym wyzwaniem diagnostycznym. W rejonie głowy i szyi, poza klasyczną limfadenopatią, może objawiać się w sposób nietypowy i wymaga różnicowania przede wszystkim $z$ chorobami nowotworowymi.

Wielokrotnie opisywano między innymi przypadki powiększenia bądź guzów ślinianki przyusznej lub podżuchwowej, spowodowanych infekcją Bartonella [1, 6, 8, 9]. Zanotowano również pojedyncze przypadki chorych $z$ obwodowym porażeniem nerwu twarzowego, towarzyszacym typowej limfadenopatii lub powiększeniu ślinianki przyusznej w serologicznie potwierdzonej łagodnej limforetikulozie [10, 11]. W literaturze opisano pojedynczych chorych dobrze udokumentowanych, gdzie wtórnie dochodziło do ropnych zakażeń tkanek głębokich szyi, np. rozwoju ropnia przestrzeni przygardłowej [12, 13].

W opisywanym przypadku symptomatologia nie odbiegała wprawdzie znacząco od klasycznego obrazu klinicznego choroby kociego pazura, jednak ze względu na wiek chorego, niezaobserwowanie przez niego zmiany pierwotnej oraz brak wyraźnej informacji o uszkodzeniu skóry przez kota w wywiadzie, a także długi czas utrzymywania się objawów w procesie diagnostycznym, za najistotniejsze uznano wykluczenie choroby nowotworowej. U przedstawionego pacjenta postawienie właściwego rozpoznania możliwe było jedynie ex post na podstawie badania histopatologicznego.

\section{Wnioski}

W każdym przypadku stwierdzenia guza na szyi warto poszerzyć diagnostykę w kierunku choroby kociego pazura.

\section{P I Ś M I E N N I C T W O}

1, Ridder GJ, Boedeker CC, Technau-Ihling K, Sander A. Cat-scratch disease: Otolaryngologic manifestations and management. Otolaryngol Head Neck Surg. 2005 Mar; 132(3): 353-8.

2, Sala E, Lipiec A, Zygmunt A, Burdzel Z, Ogórek M, Chyla M. Choroba kociego pazura - przebieg kliniczny, rozpoznanie. Przegl. Epidemiol. 2006; 60: 307-313

3, Margileth A.M. Recent Advances in Diagnosis and Treatment of Cat Scratch Disease. Curr. Infect. Dis. Rep., 2000 Apr; 2(2), 141-146

4, Podsiadły E, Sokołowska E, Tylewska-Wierzbanowska S. Występowanie zakażeń Bartonella henselae i Bartonella quintana w Polsce w latach 1998-2001. Przegl Epidemiol 2002; 56(3): 399-407.

5, Kuśmierczyk J, Czupryna P, Moniuszko A, Pancewicz S. Choroba kociego pazura. Lekarz miesięcznik dla $\mathrm{POZ}$ 2008, 7-8: 96-100.

6, Szymański M, Siwiec H, Gołąbek W. Choroba kociego pazura ślinianki przyusznej. Wiadomości lekarskie 2004, LVII, 11-12

7, Munson PD, Boyce TG, Salomao DR, Orvidas LJ. Cat-scratch disease of the head and neck in a pediatric population: Surgical indications and outcomes. Otolaryngol Head Neck Surg. 2008 Sep; 139(3): 358-63.

8, Malatskey S, Fradis M, Ben-David J, Podoshin L. Catscratch disease of the parotid gland: an often-misdiagnosed entity. Ann Otol Rhinol Laryngol. 2000 Jul; 109(7): 679-682

9, Kempf VA, Petzold H, Autenrieth IB. Cat scratch disease due to Bartonella henselae infection mimicking parotid malignancy. Eur J Clin Microbiol Infect Dis. 2001 Oct; 20(10): 732-3.

10, Walter RS, Eppes SC. Cat scratch disease presenting with peripheral facial nerve paralysis. Pediatrics. 1998 May; 101(5): E13.

11, Ganesan K, Mizen K. Cat scratch disease: an unusual cause of facial palsy and partial ptosis: case report. J Oral Maxillofac Surg. 2005 Jun; 63(6): 869-72.

12, Yeh SH, Zangwill KM, Hall B, McPhaul L, Keller M. Parapharyngeal abscess due to cat-scratch disease. Clin Infect Dis. 2000 Mar;30(3):599-601. Erratum in: Clin Infect Dis 2000 May; 30(5): 841.

13, Dean RL, Eisenbeis JF. Neck abscess secondary to cat-scratch disease. Ear Nose Throat J. 2004 Nov;83(11): 781-3. 